\title{
РОЗДІЛ 4. ДОШКІЛЬНА ПЕДАГОГІКА
}

\author{
КОМУНІКАЦІЯ ДІТЕЙ ДОШКІЛЬНОГО ВІКУ: \\ МОВНО-ПСИХОЛОГІЧНИЙ РАКУРС (АБСУРДНІСТЬ \\ ЯК ОДНА З ОСНОВОПОЛОЖНИХ РИС ДИТЯЧОЇ КАРТИНИ СВІТУ) \\ COMMUNICATION OF KINDERGARTEN CHILDREN: LANGUAGE- \\ PSYCHOLOGICAL VIEW (ABSURDITY AS ONE OF THE BASIC FEATURES \\ OF THE CHILDREN'S PICTURE OF THE WORLD)
}

Потреба в спілкуванні, котра виявляється вже у немовляти, виливається в органічне входження в світ дорослих таїхньої конкретної національної мови, що фрактично являє собою розгорнутий у часі акт самоідентифрікації особистості. Тому до перших кроків дитини на шляху оволодіння мовою (мовами) слід ставитися з максимальною уважністю, враховуючи специфрічність інтерпретації срізично-психічних реалій у мові дітей. Отже, концептуалізація сприйняття світу, становлення особистості дитини фріксується найперше в процесі ї оволодіння рідною та іншими мовами. Дослідники давно відзначили існування дитячої мовної картини світу, яка відображає первинний позитивний досвід дитини та початок формування ї аксіологічних орієнтацій. Але варто приділити більше уваги особливостям дитячого сприйняття трагічних $і$ шокуючих речей - таких як, наприклад, смерть, вбивство, злочин тощо. I тут має привернути особливу увагу френомен потрактування екзистенціального жаху в комічно-іронічному дискурсі, що вже зафріксовано у сорері дитячих фрольклору й літератури як жанр nonsense verse, що може трактуватися як самозахист психіки дитини від шокуючих та незрозумілих речей. На чій особливості дитячого світосприйняття справді побудовано чимало класичних творів дитячої літератури, насамперед глибинно пов'язаних з фольклором «абсурдистських мініатюр» типу анекдоту. Схильність до абсурдизації означає фрункціонування творчого принципу в мовленнєвій діяльності дитини. Це також сигнісрікує креативне начало в мовленнєвому розвитку дитини. Варто з'ясувати особливості способу кониептуалізації дійсності ma специорічність інтерпретації фрізично-психічних реалій у мові дітей, конкретно - в їхніх типових мовних реалізаціях бачення і спроб осмислення світу. Така ситуація заслуговує набути статусу однієї з кардинальних, основоположних рис дитячої картини світу, яка складається на межі знайомства зі «світом дорослого» й спалаху зародкового критичного мислення.

Ключові слова: комунікація, діти дошкільного віку, дитяча картина світу, мовленнєва діяльність, дитячий фольклор, дитяча літеpamypa.

The need for communication, which already manifests itself in the infant, translates into an organic entry into the world of adults and their specific national language, which is in fact a timehonored act of self-identification. Therefore, the first steps of the child in the acquisition of the language (s) should be treated with utmost care, given the specificity of the interpretation of physi$\mathrm{cal}$ and mental realities in the language of children. Thus, the conceptualization of the perception of the world, the development of the child's personality is recorded first in the process of mastering his mother tongue in other languages. Researchers have long noted the existence of a children's language picture of the world, which reflects the primary positive experience of the child and the beginning of its formation of axiological orientations. But it is worth paying more attention to the peculiarities of children's perceptions of tragic and shocking things - such as death, murder, crime, etc. The phenomenon of the treatment of existential horror in comic-ironic discourse, which has already been fixed in the field of children's folklore and literature, as a nonsense verse genre, which can be interpreted as self-defense of the child's psyche against shocking and incomprehensible things, should also be given special attention here. This feature of children's perceptions really builds on many classic works of children's literature, first of all, deeply related to the folklore of "absurdist miniatures" such as anecdotes. The tendency to absurdity means the functioning of the creative principle in the speech activity of the child. It also signifies a creative start in a child's speech development. It is necessary to find out the peculiarities of the way of conceptualization of reality and the specificity of the interpretation of physical and mental realities in the language of children, specifically in their typical linguistic realizations of vision and attempts to make sense of the world. This situation deserves to acquire the status of one of the cardinal, fundamental features of the children's picture of the world, which is on the verge of becoming acquainted with the "adult world" and the outbreak of rudimentary critical thinking. Key words: communication, preschool children, children's picture of the world, speech activity, children's folklore, children's literature.
Київського національного університету культури і мистецтв національною мовою [1, с. 3]. Ця спрямованість невідворотно посилюється у процесі дорослішання й увінчується врешті-решт свідомою мовно-національною самоідентифрікацією: «За столом зібрались гості <..> дев'ятирічний син наших друзів усе намагався щось сказати, та захоплена бесідою
Давно відзначено: «Потреба в спілкуванні виявляється вже у немовляти. Мати спілкується з дитиною, власне, ще до її народження», причому «немовля віком 3-5 днів уже засвоює певний інтонаційний малюнок рідної мови» і навіть «плаче своєю», тобто 
компанія дорослих, включаючи його матір, не звертала на нього уваги. Врешті-решт, хлопчик не витримав і крикнув, звертаючись до матері:

Ima, tni li - ani yeled! (іврит).

Мамо, приділи мені увагу - я дитина!

Хлопчик, який вільно володів двома мовами російською та івритом, вимагав поваги саме на івриті, й, обґрунтовуючи свою вимогу, поставив наріжним каменем свій статус - статус ізраїльської дитини. Безумовно, інтуїтивний вибір івриту дозволив хлопчикові узгодити мову й самосприйняття та надав почуття впевненості у своїх діях» [5, с. 58].

Отже, концептуалізація сприйняття світу, становлення особистості дитини фріксується найперше в процесі її оволодіння рідною та іншими мовами. Тому до перших кроків дитини на шляху оволодіння мовою (мовами) слід ставитися 3 максимальною уважністю.

Аналіз останніх досліджень і публікацій. Дослідники проблеми у більшості своїй віддавна дотримуються концепції антропоцентричності мови. Про існування дитячої мовної картини світу, яка відображає первинний позитивний досвід дитини та початок формування ії аксіологічних орієнтацій, писали визначні психологи нашого часу: К. Бюлер, А. Валлон, Л. Виготський, А. Лурія, Ж. Піаже, В. Штерн та ін. Конкретно ж цій проблемі присвячено чимало розвідок як у вітчизняній, так і у зарубіжній науковій думці, але анонсована нами в назві статті проблема абсурдності, як невід'ємної складової частини дитячого світу, усе ж таки не стає об'єктом самостійної уваги. Обмежимося кількома репрезентативними прикладами. Так, особливості мовленнєвого спілкування дорослих вивчено детально та розгалужено; справляє враження, скажімо, поділ мовних стратегій на кооперативні (неконорліктні): обмін думками, поради, розповіді; некооперативні (конорліктні): суперечки, претензії, погрози, ухиляння від відповідей та ін. [3, с. 119]. Однак варто врахувати й позицію іншої української дослідниці, яка, відзначивши принагідно усі ці досягнення, водночас справедливо вважає: «стратегічний процес не можна вкласти в межі алгоритму чи певних правил, що зумовлює значні труднощі в опануванні ними» [8, с. 72]; додамо: особливо коли йдеться про дошкільний дитячий вік. Й справді, дослідники дитячого мовлення охоче тяжіють до широких планів та панорамних узагальнень. Вони, наприклад, широко спираються на підсвідомі архетипи та культурні стереотипи, які складаються у колективному підсвідомому та ритуалах і традиціях такого народу, наприклад, у таких далеких одна від одної системах, як російська й китайська мови (і там і там чоловіки - агресивні, грубі, самовпевнені, незалежні, тяжіють до домінування, а жінки - слабкі, пасивні, залежні, невпевнені в собі, емоційні тощо) [5]. 3 іншого боку, утвердилося розуміння дитячого мовного простору як сукуп- ності суто позитивних знань про «зовнішній світ» та певної системи моральних оцінок, що сумарно закріплено в системі засобів користування живою розмовною (меншою мірою - писемною) мовою [10, с. 5]. Утім, як наслідок, ми нерідко стикаємося тут, у разі серйозно обґрунтованих методологічних підстав, із методикою, побудованою на дещо надмірно деталізованій описовості, опорою переважно на матеріал безпосереднього нотування розмов з дошкільниками [2, с. 66].

Виділення не вирішених раніше частин загальної проблеми. Тому варто приділити більше уваги особливостям дитячого сприйняття інформації, зумовленим непідготовленістю дитячої психіки до осягнення складних, часом трагічних і шокуючих речей екзистенціального порядку - таких як, наприклад, смерть, вбивство, злочин тощо.

Формулювання цілей статті (постановка завдання). Ми маємо на меті дослідити особливості способу концептуалізації дійсності та специфрічність інтерпретації фрізично-психічних реалій у мові дітей, конкретно - в їхніх типових мовних реалізаціях бачення і спробах осмислення світу.

Виклад основного матеріалу дослідження. Людям властиво губитися перед наявністю зла в світі, тому так багато язичницьких релігій та світських моралізаторських концепцій, прагнучи пояснити або й виправдати існування зла, вчать, що добро і зло мають спільний корінь або ж мусять шануватися нарівно. Це породжує примирення 3 жорстокістю, яка, власне, коріниться у твариннобіологічному підґрунті людської істоти як частини природного світу, й сприймається як закономірна й необхідна. Інтерполюючи ситуацію на все, що нас оточує, багато хто вважає зло неодмінним атрибутом Всесвіту, ігноруючи, наприклад, християнську теодицею - виправдання Бога за існування зла в світі: згідно з теодицеєю, зло породжується бунтом Творіння проти Творця і є продуктом вільного вибору, оскільки багато хто не вміє користуватися свободою та йде найлегшим шляхом примирення з існуванням зла. Тому одне із завдань нашої традиційної культури - пом'якшити шок, який породжується в свідомості дитини, котра вперше починає розуміти масштаби й силу влади зла в навколишній дійсності.

Збентеження, викликане незрозумілістю й небезпеками світу, в який входить дитина, органічно й часом нерозривно пов'язується з довірою до світу, 3 первісною вітальною радістю буття Так, перший сміх у немовляти з'являється вже в 2-4 місяці; тут для вибуху дитячого сміху потрібні поцілунки, лоскотання та подібні ігри; в другі ж півроку до тактильних подражнювачів додається вже й візуально-слуховий компонент, і дитина починає розпізнавати абсурдні ситуації, коли, наприклад, мама підходить до неї із заплющеними очима, мурмочучи при цьому, та починає її шукати намацуванням. Характерно втім, 
що тут веселощі в будь-який момент можуть змінитися на переляк та істерику.

А в дошкільний період діти все частіше граються у війну й агресивно, безкінечно «вбивають» одне одного; дорослі ж активно використовують ситуацію, запроваджуючи в дитячих садках дидактичні ігри типу «Що таке добре, а що таке погано» (скажімо, гра в «отруйні гриби»). При цьому дослідників не занадто часто приваблювала виразна схильність дитини до, так би мовити, «перебору», який характерний для створюваної в дитячому мовленні картини світу, охоче оперування абсурдністю та алогічністю.

Не можна сказати, що такий момент дитячого світосприйняття цілковито ігнорувався. Л. Вітгенштейн розглядав усілякі жарти, використання неточного перекладу й взагалі сореру комічного у її вербальній реалізації як важливий складник мовної гри [4, с. 90]; відштовхуючись від цієї концепції, Ю. Каховська фріксує: «Мовна гра займає доволі велике місце в ситуації спілкування між дорослим і дитиною. Виступаючи френоменом мовної взаємодії, цей прийом базується на відхиленні від стереотипів і прагненні добитися еоректу, який, своєю чергою, сприяє успішному протіканню комунікативної взаємодії. Подібні конструкції мають відтінок гостроти, жарту, іронії, каламбуру; вони можуть включати загальновідомі цитати з популярних кінофрільмів, текстів, спектаклів і пісень» [6, с. 115]. Та при цьому в мовленнєвій практиці спілкування дітей з дорослими, одне з одним, й у дитячому фрольклорі стабільно фрігурують абсурдні й жахливі речі, які інтерпретовані в комічно-іронічному дискурсі. Усе це бурхливим потоком переливається у дитячу літературу: це «Аліса у Дивокраї» Л. Керрола й популярна на Заході «Книга Нонсенс» Е. Ліра, а також «Казки матінки моєї Гуски» Ш. Перро і взагалі фрольклор як джерело усіх цих «нісенітниць»; такі літературні мініатюри пов'язані із грою, драматизацією. «Горобець кричить, річка горить, а кіт читає книжку! Таке буває в дитячих віршах - віршах, які із задоволенням читають і діти, і дорослі», - відзначає Н. Фьодорочева й подає розгорнуте визначення такого жанру: це - «поезія абсурду (nonsense verse), жанр гумористичної поезії, в якій свідомо використовуються незвичні, позбавлені сенсу слова й припустима алогічність» $[11$, с. 6,8$]$.

Залишається перейти до того, що все це означає, найперше, самозахист психіки дитини від шокуючих та незрозумілих речей. На цій особливості дитячого світосприйняття справді побудовано чимало класичних творів дитячої літератури, насамперед глибинно пов'язаних 3 фольклором «абсурдистських мініатюр» типу анекдоту (згадані Л. Керрол і Е. Лір, К. Чуковський і Д. Хармс тощо). Саме в цьому дистанціюванні від «правильного» Космосу Дорослих дитина відчуває себе здатною до «перестворення світу», для неї відкриваються креативні можливості.
Тому «мають рацію ті дослідники, які розглядають «неправильне» вживання слова дитиною не тільки як результат бідності словника дитини або як знак нерозуміння конвенційного вживання значення слова і незнання норм його системного функціонування, але і як доказ яскравого творчого начала в мовленнєвій діяльності дитини» [7, с. 10].

Висновки. Очевидно, що йдеться не про випадкову й побічну ситуацію, а про принципову особливість дитячого світосприйняття, яке опановує речі, від початку абсурдні й непосильні для розв'язання навіть у свідомості дорослого. Це - травма дитинства, 3 якою має мужність жити кожна людина, долаючи екзистенціальний жах. Але ситуація дає й можливості для фрормування психологічних шляхів до зрозуміння таких оптимістичних концепцій, як, наприклад, згадана вище християнська теодицея, що в річищі наших проблем духовного відродження нації постає не останнім завданням. Тому така ситуація заслуговує набути статусу однієї з кардинальних, основоположних рис дитячої картини світу, яка складається на межі знайомства зі «світом дорослого» й спалаху зародкового критичного мислення.

\section{БІБЛІОГРАФІЧНИЙ СПИСОК:}

1. Абрамович С.Д., Чікарькова М.Ю. Мовленнєва комунікація : підручник. Київ : ВД Дмитра Бураго, 2013. 464 с.

2. Анохина В.С., Кравченко О.В. Разговоры с детьми: стратегии и тактики речевого поведения. Филологические науки. Вопросы теории и практики. Тамбов : Грамота, 2018. № 12 (90). С. 66-70.

3. Бацевич Ф.С. Основи комунікативної лінгвістики. Київ : Академія, 2004. 344 с.

4. Витгенштейн Л. Философские работы. Ч. 1. Москва:Гнозис, 1994. 612 с.

5. Збаневич К. Два мира одного детства: дискурсанализ опыта взросления в Израиле. Laboratorium. 2010. № 3. C. 58-71.

6. Каховская Ю.В. Языковая игра в речевом взаимодействии «взрослый - ребенок». Вестник РУДН. Серия «Вопросы образования: язык и специальность». 2015. № 1. С. 115-120.

7. Кубрякова Е.С. Специфика актов референции в детской речи. Детская речь: проблемы и наблюдения. Ленинград : Изд-во ЛгПИ, 1989. С. 4-22.

8. Оліяр М. Стратегії і тактики педагогічної комунікації. Гірська школа українських Карпат. 2016. № 15. C. 72-76.

9. Пилюгина Н.Ю. Результаты эксперимента по исследованию гендерных особенностей ассоциативных полей «Мужчина» и «Женщина» в русском и китайском языке. Территория новых возможностей. 2016. № 3 (34). С. 167-175.

10. Тухарели Н.Л. Детская языковая картина мира как предмет лингвистического изучения. Язык, сознание, коммуникация : сб. статей. Вып. 17. Лингвистика. Москва : МАКС Пресс, 2001. С. 5-9.

11. Фёдорочева Н.Б. Кое-что о «витамине роста», или Родителям о детской поэзии абсурда. Библиотечное дьло. 2014. № 24 (234). С. 8-10. 